\title{
Study on the Utilization of the Child-Adolescent Functional Assessment Scale in Mental Health Service
}

\author{
Kyung Ran Row \\ Seoul Metropolitan Songpa Aizone, Seoul, Korea
}

\author{
정신건강서비스 영역에서 아동청소년 기능평가척도의 활용에 관한 연구 \\ 노 경 란 \\ 서울시 송파아이존
}

\begin{abstract}
Objectives: This study aims to supplement the limitations of the preliminary study and expand the use of the Child-Adolescent Functional Assessment Scale by providing standardized T-scores for measuring function in different areas, as well as guidelines for their interpretation. Methods: The Child-Adolescent Functional Assessment Scale and Korean-Child Behavior Checklist were administered to a total of 623 individuals, including 467 parents of emotionally and behaviorally disturbed elementary school students, 45 parents of emotionally and behaviorally disturbed middle school adolescents and 111 parents of elementary school students with developmental disorders, as well as to a control group consisting of 186 parents of mainstream elementary school children in the Seoul metropolitan area.

Results: In contrast to the preliminary study, the emotional domain was disassociated into two factors, negative affect and emotion regulation, and the coefficient of determination for misconduct was increased significantly. Also, the overall reliability and validity of the ChildAdolescent Functional Assessment Scale were similar to those in the preliminary study, and the item structure was consistent. This study provides standardized T-scores of function in different areas based on the revised scale, and provides guidelines for their interpretation.

Conclusion: The Child-Adolescent Functional Assessment Scale can assist the Child Global Assessment in Functioning in providing the information necessary for case management and treatment planning by comparing the impairment severity in each area of functioning, and also determining changes in behavior and function after treatment interventions. On the other hand, this scale has yet to clearly distinguish between rebellious behavior and misconduct. Further research is necessary to provide standards for more diverse age groups and for its utilization.
\end{abstract}

Key Words: Functional Assessment Scale; Children and adolescents; Mental health service; Validation; Utilization.

Received: December 3, 2016 / Revision: February 27, 2017 / Accepted: April 17, 2017

Address for correspondence: Kyung Ran Row, Seoul Metropolitan Songpa Aizone, 17 Chungmin-ro 6-gil, Songpa-gu, Seoul 05792, Korea

Tel: +82-2-2144-1141, Fax: +82-2-2144-1146, E-mail: krjwsy@hanmail.net

\section{서 론}

최근 들어 정신건강 서비스 분야에서는 치료 서비스의 성과 와 만족도를 측정하는 것이 점차 필수로 되어가는 추세이다. 그러나 정신건강 서비스, 특히 아동청소년을 위한 공공 서비 스 분야에서 효과검증이나 비용-대비 효과성에 대해 증거에 기반한 연구는 거의 없는 실정이다. 서비스 성과에 대한 평가 는 임상적 치료에 대한 평가와 서비스 효과성에 대한 평가로 크게 구분할 수 있다. 임상적 치료에 대한 평가는 개인적 차원

This is an Open Access article distributed under the terms of the Creative Commons Attribution Non-Commercial License (http://creativecommons.org/licenses/by-nc/4.0) which permits unrestricted non-commercial use, distribution, and reproduction in any medium, provided the original work is properly cited.
에서 증상 감소에 주로 초점을 두는 반면, 서비스 효과성에 대 한 평가는 서비스 수준의 변화를 주 목표로 하는 서비스 효과 성에 대한 평가로 나눌 수 있다. ${ }^{1)}$ Hogwood 등 ${ }^{2}$ 은 아동청소년 의 치료서비스 효과를 폭넓게 이해하고 검증하기 위한 모델로 서 Symptom Functionining Consumer Environment System (SFCES)을 제시하였다. SFCES는 포괄적인 효과검증 모델로 서 증상과 진단(symptoms and diagnoses), 가정, 학교와 지 역사회에서의 기능(functioning), 소비자 관점(consumer perspectives), 아동 주요환경의 안정성(environments), 그리고 체 계(systems)의 다섯 가지 영역을 포함하고 있다.

SFCES 모델에 비추어 볼 때, 국내의 아동청소년 정신건강 서 비스 영역에서 아동청소년의 치료 효과를 검증하기 위한 평 
가도구는 대부분 특정 증상과 진단에 초점을 맞춘 척도들이 다. 예를 들면, 아동용 우울척도(Children's Depression Inventory), 주의력결핍 과잉행동장애를 측정하기 위한 attentiondeficit hyperactivity disorder 평정척도(Attention-Deficit Hyperactivity Disorder Rating Scale)나 코너스 평정척도(Conner's Rating Scale)가 있다. 또한 전반적인 증상을 포괄적으로 측 정하는 척도로서 한국판-아동청소년 행동평가척도(KoreanChild Behavior Checklist, $\mathrm{K}-\mathrm{CBCL}$ )와 $\mathrm{K}-\mathrm{CBCL}$ 보다 간단 하며 선별검사용 척도인 아동 정서·행동발달 선별검사(Child Problem-Behavior Screening Questionnaire)가 있다. 이러한 평가도구들은 부모(혹은 교사)가 아동의 증상을 위주로 평정 하는 척도들이다.

Jensen 등른 아동청소년 정신건강서비스의 효과를 측정 할 때 단순히 증상 감소의 측면뿐만 아니라, 기능 영역의 측정 이 필요하다고 보았다. Bird 등의 읜구 결과에 의하면 진단 그 자체만으로 서비스의 필요성을 예측해주지 않는다는 보고 들이 있다. 기능이란 가정, 학교, 또래관계, 지역사회에서 요구 하는 다양한 요구에 적응하는 능력을 의미하는 측면과 정서 행동 및 사회적 증상으로 인해 다양한 세팅에 적응하는데 얼 마나 손상이 되었는가를 의미하는 측면, 모두를 포함한다. 정 신건강 서비스 영역에서 기능을 언급할 때는 주로 기능적 손상 을 의미한다. 아동청소년의 주 호소 문제는 파괴적이거나 일탈 된 행동, 기능 감퇴가 대다수를 차지하므로 진단할 때 아동의 기능 손상 정도를 고려하는 것이 매우 중요하다. 또한 아동청소 년들이 정신건강 서비스를 활용하는지 여부를 예측하는 가장 중요한 요소도 역시 심리사회적 기능인 것으로 알려져 있다.")

정신장애 진단 및 통계 편람(Diagnostic and Statistical Manual of Mental Disorders, DSM)에서 대부분의 정신장애를 진 단할 때, 증상에 대한 기준 외에도 별도의 기준으로서 심리사 회적 손상이나 고통을 요구한다. DSM 내에서 증상에 대한 기준은 잘 확립되어 있는 반면, 심리사회적 기능 손상에 대한 정의나 기준은 아직 불분명하며 통일되어 있지 않다. ${ }^{5)}$ 정신장 애 진단 및 통계 편람의 개정된 4판에는 아동청소년의 기능을 측정하기 위한 도구로서 아동총괄기능평가척도(Child Global Assessment in Functioning, CGAS)를 제시하였다. CGAS는 18 세 아동청소년을 대상으로 그들의 전반적인 기능손상 정도 를 평가하기 위한 도구이며, 성인을 대상으로 한 총괄기능평 가척도(Global Assessment of Functioning, GAF)를 아동청 소년 연령층으로 확장한 것이다. CGAS는 임상가가 정신건강 (100점) 상태로부터 정신질환(0점)에 이르기까지 연속선상에 서 평가하며, 시간경과에 따라 호전 또는 악화되는 정도나 치료 결과를 평가하는 데 유용하다.) 임상가가 환자에 대한 정보를 충분히 갖고 있다면 짧은 시간 내에 쉽게 실시할 수 있기 때문
에 이 척도는 전반적인 정신장애를 평가하는 척도로서 임상이 나 연구 장면에서 가장 널리 활용되어 왔다. CGAS는 단일 차 원의 전반적인 기능평가척도이기 때문에 편리한 점도 있는 반 면, 몇 가지 단점도 있다. 첫째, 신뢰도 및 타당도를 유지하기 위해서 평가자에 대한 훈련이 필수적으로 요구된다. 연구 장면 에서 CGAS의 평정자 간 신뢰도는 0.83 에서 0.9 로 보고되지만, 실제로 임상장면에서의 신뢰도는 중간 이하(0.66이나 그 미만) 인 것으로 알려져 있다. ${ }^{5)}$ 둘째로, 다양한 영역에서의 심리사회 적 기능들 간에 구분을 하지 않고, 임상가가 단일한 수치로 요 약되는 판단을 한다. 그러므로 어느 영역에서 손상이 있으며, 어떤 손상이 있는지 불분명하다. 특히 증상 심각도와 기능 손 상이라는 두 개의 다른 개념이 하나의 전반적인 평가에 합쳐졌 기 때문에, 척도의 구성타당도를 감소시킨다. 마지막으로, 이 척 도는 각 연령군마다 정상 혹은 평균치가 무엇인지에 대한 정보 가 없다는 단점이 있다.

2013년도에 출판된 DSM-5는 기존의 다축체계를 가진 유형 별 진단분류가 사라지고 축이 없는 차원적인 진단분류체계로 변화되었다. 이에 따라, 기능평가를 보고하는 제 5 축도 사라지 게 되었으며, 총괄기능평가척도(GAF)도 DSM-5에서 배제되 었다. DSM-5는 GAF 대신에 World Health Organization Disability Assessment Schedule II(WHODAS II)라는 새로운 전반적 기능 및 손상 평가도구를 사용하도록 권장하고 있다. DSM-5에서 아동의 경우는 CGAS 대신 성인용 WHODAS II 으로부터 나온 아동용 WHODAS II를 사용하도록 권장하고 있다. 아동용 WHODAS II는 부모용, 청소년용, 임상가용 버전 이 있으며, 6 가지 영역, 즉 이해와 의사소통, 돌아다니기(가동 성), 자기 돌보기, 사람들과 지내기, 생활 활동(학교와 학교 외), 사회 참여의 영역을 측정한다. ${ }^{7)}$ 아동용 WHODAS II는 International Classification of Functional Disability and Health for Children and Youth(ICF-CY)에 근거하였으며, ${ }^{8)} \mathrm{ICF}-\mathrm{CY}$ 는 신체적으로나 발달적으로 장애가 있는 아동들에게 주로 시행되어왔다. 그러므로 정신장애나 정서장애를 가진 아동들 에게 이를 적용하는 데 한계가 있는 것으로 보인다. 아울러 아 동용 WHODAS II는 증상과 의학적 질병이나 정신장애로부 터 유발된 기능 손상을 별개의 구성개념으로 구분하는 반면, $\mathrm{DSM}-5$ 에는 정신장애와 그와 관련된 고통이나 기능손상 간에 중첩이 존재한다. 더욱이, 아동들의 정신장애나 정서장애는 공병 진단이 빈번하기 때문에 기능 손상의 원인이 그 진단의 증 상에 기인한 것이라고 귀인하기 매우 어려운 경우가 흔하다. ${ }^{9}$ WHODAS II는 측정도구로써의 속성은 적절하지만, 제한점 이 몇 가지 있다. ${ }^{10}$ 첫째, WHODAS II는 기능 손상과 진단적 인 고려점을 명확하게 구분하는 international classification of disease(ICD) 질병 모델을 반영한다. 반면에 DSM-5의 진단 
준거는 임상적으로 중요한 고통이나 기능 손상을 필수요건으 로 포함한다. 그러므로 기능손상이란 개념을 내포한 DSM-5 의 정신장애에 대한 정의와 기능손상 개념을 포함하지 않는 ICD 정신장애 정의 간에 큰 갈등이 존재한다. 따라서 진단을 위해 DSM-5을 사용하면서 동시에 ICD에 기반한 새로운 기능 평가척도를 도입할 때 혼란의 소지가 있어 보인다. 둘째, $\mathrm{WH}-$ ODAS II은 규준이나 비교할 만한 값이 아직 없는 실정이다.

국내의 정신보건영역에서는 아동청소년의 증상보다는 기능 을 측정하기 위한 도구로 지금까지 CGAS가 주로 사용되고 있다. 그러나 CGAS는 전반적인 단일 점수로만 산출되기 때 문에, 지역사회에서 선별 목적 외에 아동의 전후 변화된 부분 을 민감하고 간편하게 측정함으로써 사례관리나 치료계획에 도움을 주는 데 활용할 수 있는 척도가 부재한 실정이었다. 이 러한 CGAS의 제한점을 보완하고, 어느 영역에서(가정, 학교, 또래관계 및 학업, 정서, 행동, 특수 영역), 어느 정도의 기능 손상을 보이는지 좀 더 구체적으로 파악할 수 있는 도구가 절 실히 요구되었다. 이러한 현장의 필요에 기반하여 본 연구의 아동청소년 기능평가척도는 아동의 증상보다 기능손상 정도 를 평가하는 데 더 초점을 맞추고, 부모 보고에 의한 평가가 아니라 지역사회 사례관리 실무자나 임상가가 평가하되, 단시 간 내에 좀 더 영역별로 세분화된 구체적인 정보를 얻을 수 있 으며, 선별검사가 아니라 변화 정도를 추적함으로써 사례관리 나 치료계획에 도움을 줄 수 있게 하기 위하여 개발되었다.11) 만 6세부터 15세에 해당되는 아동청소년을 대상으로 개발된 국 내 아동청소년 기능평가척도는 미국의 Child and Adolescent Functional Assessment Scale(CAFAS) $)^{12}$ 과 호주의 Health of the Nation Outcome Scale Children and Adolescents $(\mathrm{HoNOSCA})^{13)}$ 와 같은 대표적인 해외의 아동청소년기능평가 척도 문항들을 비교 분석한 뒤, 이를 토대로 하여 한국 실정 에 맞는 척도를 제작하였다. 기존 CGAS의 제한점을 보완하 여 하위영역을 행동(가정, 학교 또는 지역사회), 또래관계 및 학업, 정서, 특수 영역(자해 및 자살, 중독, 정신병적 영역)으로 나누어 소척도를 구성하였으며, 총 47문항으로 만들어졌다.11) 아동청소년 기능평가척도의 신뢰도는 품행 행동을 제외한 대 부분의 문항에서 0.70 이상의 높은 신뢰도를 보였으며, 문항 변별도는 행동영역의 품행문제 영역과 특수척도 문항을 제외 하고 0.411 0.758로 높게 나타났다. 타당도 검증을 위해서 $\mathrm{K}-$ $\mathrm{CBCL}$ 과 각 요인의 상관분석을 실시한 결과, $\mathrm{K}-\mathrm{CBCL}$ 총 문 제 행동과 기능평가 전체 문항이 0.610 으로 매우 유의미한 상 관을 나타냈다. 그러나 아동청소년 기능평가척도의 제한점으 로는 우선 탐색적 요인분석을 실시한 결과, 품행, 비행문제 문 항에서 선별이 적절히 되지 않았는데, 이는 대상이 초등학생 으로 한정되어 있었기 때문인 것으로 설명되어 추후 청소년을
포함한 좀 더 다양한 연령층과 임상군에 적용할 필요성이 시 사되었다. 또한 척도 규준이 원점수로 작성되어 있어서 기능 점수로 개인 내 영역 간 비교가 어려운 제한점을 나타냈다.

따라서 이러한 예비연구의 제한점을 보완하고 아동청소년 기능평가척도를 좀 더 다양하게 활용하기 위하여, 본 연구는 다양한 임상집단과 중학생 연령층에 아동청소년 기능평가척 도를 실시한 결과를 토대로 영역별 표준화된 T점수 기준 및 해석 가이드라인을 제시하고자 한다. 이를 통해 아동청소년 기능평가척도가 정신보건시스템 내에서 개입효과를 세분화하 여 검증하고 사례관리와 치료계획에 필요한 정보를 제공하는 데 활용되도록 하고자 한다.

\section{방 법}

\section{대 상}

본 연구의 임상군은 2014년 12월부터 2015년 12월까지 정서 행동문제로 7개 지역의 아이존(노원, 동대문, 동작, 서초, 송파, 양천, 중구)을 이용하는 초등학생 총 467명, 발달장애로 4 개 지역의 아이존(종로, 금천, 강서, 서대문)을 이용하는 발달장애 아동 총 111 명, 그리고 정서행동문제로 푸른존을 이용하는 중 학생 총 45 명, 모두 합해 12 개 기관을 이용하는 임상군 아동청 소년 총 623 명의 보호자들을 대상으로 서면동의를 받은 후 아동청소년 기능평가척도와 $\mathrm{K}-\mathrm{CBCL}$ 을 실시하였다. 통제집단 은 서울 소재 초등학교에 다니는 아동의 보호자들 186 명으로 부터 표집되었으며, 이들의 서면동의서를 받은 후 동일한 아동 청소년 기능평가척도와 $\mathrm{K}-\mathrm{CBCL}$ 이 실시되었고, 참여자들에 게는 소정의 참가비가 지불되었다. 통제집단은 예비연구 ${ }^{11}$ 와 동일하다. 표집대상의 분포는 Table 1에 제시되었다. 본 연구는 공용기관 생명윤리위원회의 심사 및 승인을 받았다(IRB 승인 번호: P01-201504-22-001).

\section{측정도구}

\section{아동청소년 기능평가척도(Child-Adolescent Functional}

Assessment Scale)

본 척도는 만 6 세부터 15 세에 해당되는 아동청소년을 대상 으로 증상 자체보다는 증상으로 인한 기능손상 정도를 알아 보기 위해서 Row와 $\mathrm{Suh}^{11}$ 가 개발하였으며, 정신보건서비스 영역의 실무자들을 위한 척도이다(Appendix). 이 척도는 선별 목적이 아니라, 전후 기능상 변화된 점을 민감하게 측정하는 데 초점을 두었으며, 행동(가정과 학교로 구분), 정서(장소 구 분 없음), 사회성 및 학업(학교), 특수 영역(장소 구분 없음)으 로 나누어 소척도를 구성하였다. 행동을 평가하는 척도는 가 
Table 1. Demographic data of subjects $(n=809)$

\begin{tabular}{|c|c|c|c|c|c|}
\hline & Total (\%) & Clinical group 1 (\%) & Clinical group 2 (\%) & Clinical group 3 (\%) & Control (\%, \\
\hline Total & 809 & 467 & 111 & 45 & 186 \\
\hline \multicolumn{6}{|l|}{ Sex } \\
\hline Male & $548(68)$ & $352(75.5)$ & $68(61.8)$ & $26(57.8)$ & $102(55.1)$ \\
\hline Female & $258(32)$ & $114(24.5)$ & $42(38.2)$ & $19(42.2)$ & $83(44.9)$ \\
\hline \multicolumn{6}{|l|}{ Age } \\
\hline Preschool & $43(5.3)$ & $6(1.3)$ & $37(33.3)$ & & \\
\hline Elementary: lower grades & $356(44.1)$ & $236(50.5)$ & $50(45.0)$ & & $70(37.8)$ \\
\hline Elementary: upper grades & $368(45.5)$ & $223(47.8)$ & $19(17.1)$ & $11(24.4)$ & $115(62.2)$ \\
\hline Middle school & $41(5.1)$ & $2(0.4)$ & $5(4.5)$ & $34(75.6)$ & \\
\hline
\end{tabular}

Clinical group 1: elementary students with emotional \& behavioral disturbances, Clinical group 2: elementary students with developmental disorders, Clinical group 3: middle school students with emotional \& behavioral disturbances

정과 학교에서 각각 주의력 및 과잉행동문제, 반항문제, 품행 문제의 3개 영역으로 이루어져있다. 정서 영역은 부적 정서, 정 서조절의 2 가지 영역으로 구성되어 있다. 사회성 및 학업 영역 은 학교장면만 포함하였으며, 특수 영역에는 고위험군 선정을 위해 자해 및 자살, 중독, 정신병적 영역의 3가지 영역이 포함 되어 있다. 총 47문항으로 구성되었으며, 각 영역별 하위점수 는 가정행동 영역 10점, 학교행동 영역 9점, 사회성 및 학업 16 점이고, 정서 영역의 부적 정서 7점, 정서조절 3점, 특수 영역 14 점으로 총점은 59점이다. 아동청소년 기능평가척도의 신뢰 도는 행동영역의 품행문제를 제외하고 0.70 이상의 내적 일관 성을 보였고, 문항 변별도는 품행 및 특수 영역을 제외하고 $0.411 ~ 0.758$ 이었다. 타당도 검증을 위해 $\mathrm{K}-\mathrm{CBCL}$ 총 문제 행동 과 기능평가척도 전체문항과의 상관이 0.610으로 매우 유의미 한 상관을 나타냈다. ${ }^{11)}$

\section{아동청소년 행동 평가 척도(Korean Child Behavior Checklist)}

현재 우리나라에서 가장 많이 사용하는 아동청소년 행동평 가 질문지인 $\mathrm{K}-\mathrm{CBCL}$ 은 본 연구에서 아동청소년 기능평가척 도의 공존타당도를 검증하기 위해 함께 사용되었다. $\mathrm{K}-\mathrm{CBCL}$ 은 Achenbach ${ }^{14,15)}$ 가 제작한 아동, 청소년 행동평가 척도(Child Behavior Checklist)를 오경자, 이혜련, 홍강의, 하은혜가 번역, 표준화되어 널리 사용되고 있다. $\mathrm{K}-\mathrm{CBCL}$ 은 크게 사회능력 척도(Social Competence Scale)와 문제 증후군 척도(Behavior Problem Scale)로 구성되어 있다. 문제 행동 척도는 119 개의 문제 행동에 관한 항목으로 구성되어 있는데 각 항목은 3점 척도로 평가되어 각 문제 행동 증후군 척도는 해당 문제 행동 항목들의 합으로 계산된다. 문제 행동 증후군 척도는 위축 척 도, 신체 증상 척도, 우울/불안 척도, 사회적 미성숙 척도, 사 고의 문제 척도, 주의집중 문제 척도, 비행 척도, 공격성 척도, 내재화 척도, 외현화 척도, 총 문제 행동 척도, 성 문제 척도, 정 서 불안정 척도(6 11세 만 적용) 등 모두 13 개의 척도로 구성
되어 있다. ${ }^{16)}$

\section{분석방법}

본 연구는 아동청소년 기능평가척도의 세분화된 영역별 $\mathrm{T}$ 점수 기준 및 척도활용을 위한 가인드라인을 제시하고자, 첫 째, 먼저 다양한 임상집단과 중학생 연령층에 아동청소년 기 능평가척도를 실시한 결과를 예비연구의 결과와 비교하여 본 척도의 타당성을 검증하였다. 신뢰도는 소문항의 내적 일관성 을 통해 검증하였다. 공존타당도는 아동청소년 기능평가척도 의 각 요인과 $\mathrm{K}-\mathrm{CBCL}$ 간의 상관분석을 실시하여 확인하였으 며, 구인타당도는 행동(가정과 학교), 학업 및 또래관계, 정서, 특 수 영역 각각에 대해 연구자가 지정한 3 요인수로 고정하여 확 인적 요인분석으로 검증하였다. 임상집단과 통제집단 간 변별 타당도 검증을 위해 집단별 일원 analysis of variance(ANOVA) 를 실시한 뒤, Scheffe 사후검증을 통해 영역별로 집단 간 유 의한 차이를 확인하였다. 둘째, 예비연구와 달리 원점수로 작 성된 규준을 $\mathrm{T}$ 점수로 변환하여 개인 내 영역 간 비교가 가능 하도록 하였다. 그리고 세분화된 영역별 $\mathrm{T}$ 점수 기준과 함께 척 도활용에 대한 가이드라인을 제시하였다.

\section{결 과}

\section{아동청소년 기능평가척도의 타당성 검증}

신뢰도

Table 2에 제시된 바와 같이 각 하위요인별 Cronbach alpha 를 살펴보면, 먼저 가정행동 영역에서는 예비연구 결과와 유 사하게 적정한 수준의 신뢰도를 보였다. 특히 가정 품행은 예비 척도의 신뢰도 점수 0.461 에 비해 0.584 로 다소 상승을 하였다. 학교행동에서도 이전 결과와 유사하게 적정한 수준의 신뢰도 를 갖는 것으로 나타났으며, 특히 학교 품행 영역에서 예비연 
Table 2. Reliability and Item discrimination

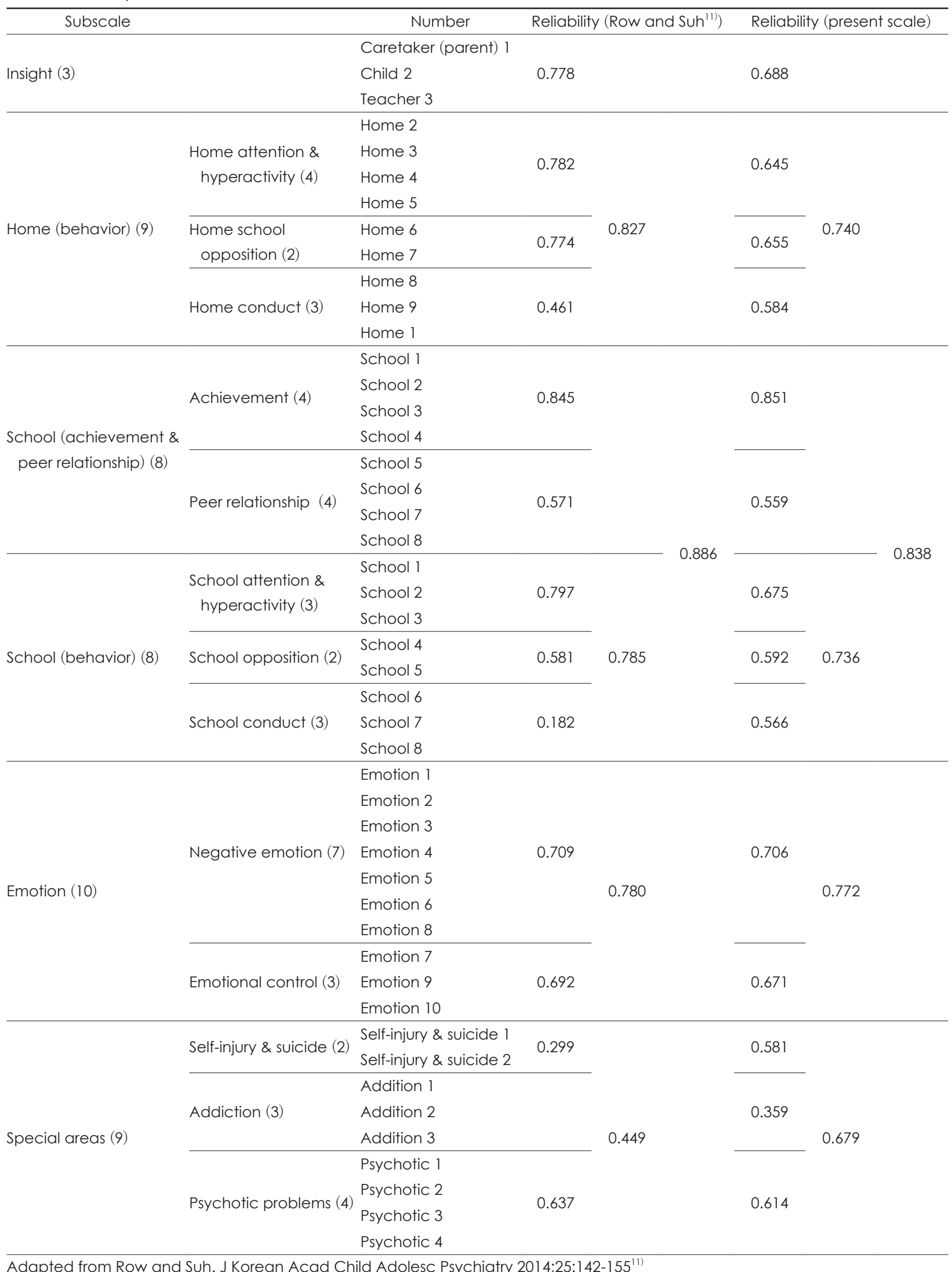

Adapted from Row and Suh. J Korean Acad Child Adolesc Psychiatry 2014;25:142-155 ${ }^{11)}$ 
구의 신뢰도 점수 0.182 에 비해 0.566 으로 신뢰도가 두드러지 게 향상되었다. 학업 및 또래관계는 학업 0.851 , 또래관계 0.559 였으며, 학업 및 또래 전체는 0.838 로 예비연구 결과와 유 사하게 적절한 신뢰도를 나타냈다. 정서 영역에서는 부적 정서 0.706 , 정서조절 0.671 로 양호한 편이었으며, 전체 정서 영역의 신뢰도는 0.772 로 예비연구 결과와 유사하게 나타났다. 이처 럼 가정행동, 학교행동, 학교성취 및 또래관계, 정서 영역에서 이전 연구와 유사하게 대부분 신뢰도가 적정한 수준으로 나타 났으며, 특히 가정 및 학교의 품행 영역에서는 이전에 비해 신 뢰도가 상승하였다. 특수 영역의 신뢰도는 자해 및 자살 0.581 , 중독 0.359 , 정신병적 영역 0.614 로 전체 특수 영역 신뢰도는 0.679 를 나타내어 예비연구에서 보고된 신뢰도 점수 0.449 에 비해 상당한 향상을 보였다.

항목-전체 상관계수(corrected item-total correlation)는 대 부분 0.311 0.749로 높게 나타났다. 그러나 품행 영역과 특수 영역의 항목-전체 상관계수가 대체로 낮은 편으로 신뢰도와 유사한 패턴으로 나타났다. 구체적으로 살펴보면 가정 품행 영 역의 가정 9 문항 변별도가 0.299 , 학교 품행영역의 학교 16,17 문항의 변별도가 $0.248,0.226$, 중독 영역의 1,2 문항의 변별도 가 $0.218,0.124$, 정신병적 사고 영역의 11,13 문항의 변별도가 $0.259,0.167$ 로 변별도의 수준이 낮은 편이었다.

\section{$\mathrm{K}-\mathrm{CBCL}$ 과의 상관관계}

공존타당도(concurrent validity)를 알아보기 위해서 $\mathrm{K}-\mathrm{CBCL}$ 총 문제 행동과 기능평가척도 전체점수와의 상관관계를 측정 한 결과 0.524 로 예비연구 결과 $(\mathrm{r}=0.610)$ 와 유사하게 상당히 유의미한 상관을 보여 아동청소년 기능평가척도의 공존타당 도가 적절함을 나타냈다. 좀 더 구체적으로 각 하위척도의 상 관을 보면, $\mathrm{K}-\mathrm{CBCL}$ 의 외현화 문제는 기능평가척도에서 총 가 정행동과 0.609 로 가장 높은 상관을 보여 예비연구 결과 $(\mathrm{r}=$ 0.610)와 거의 동일하였다. $\mathrm{K}-\mathrm{CBCL}$ 의 내재화 문제는 기능평 가척도의 부적 정서와 예비연구에서 0.456 로 가장 상관이 높은 반면, 본 연구에서는 $\mathrm{K}-\mathrm{CBCL}$ 의 내재화 문제가 부적 정서를 포함하는 총 정서 영역에서 0.458 로 가장 상관이 높았다. 특히 $\mathrm{K}-\mathrm{CBCL}$ 의 우울 및 불안, 신체증상, 그리고 위축은 기능평가 척도의 총 정서 영역과 각각 $0.487,0.355,0.358$ 수준으로 가 장 높은 상관을 나타냈다. 또한 $\mathrm{K}-\mathrm{CBCL}$ 의 사회적 미성숙은 또래관계를 포함한 총 학교문제 영역과 0.579 로 가장 높은 상 관을 보인 반면, $\mathrm{K}-\mathrm{CBCL}$ 의 사고문제는 기능평가척도에서 가 정행동 중 특히 주의집중문제와 0.541 로 높은 상관을 보였다.

본 연구에서 $\mathrm{K}-\mathrm{CBCL}$ 과 아동청소년 기능평가의 상관은 예 비연구의 상관 수준과 거의 유사하나, 예비연구의 결과와 다른 점은 $\mathrm{K}-\mathrm{CBCL}$ 외현화 영역에 속하는 비행척도가 규칙위반으
로 변경되면서 이전에는 기능평가척도의 학교 품행과 가장 높 은 상관을 보였으나, 본 연구에서는 총 가정행동 특히 주의집 중이나 반항문제와 좀 더 상관이 높은 것으로 나타났다. 아울 러 $\mathrm{K}-\mathrm{CBCL}$ 의 위축은 이전에는 가정행동과 상관이 유의하였 으나, 본 연구에서는 총 정서 영역과 학업 및 또래관계를 포함 하는 총 학교영역에서 모두 가장 높은 상관을 나타냈다. 예비 연구의 결과와 비교해볼 때, 본 연구에서는 $\mathrm{K}-\mathrm{CBCL}$ 의 위축 이나 사고 문제와 같은 영역에서 좀 더 높은 공존타당도를 나 타냈다.

반면에 $\mathrm{K}-\mathrm{CBCL}$ 총 문제 행동과 기능평가척도 전체점수와 의 상관관계가 집단별로 어떤 차이를 보이는지 분석해본 결과, 통제집단에서 0.597 로 $\mathrm{K}-\mathrm{CBCL}$ 총 문제 행동과 기능평가척 도 전체점수의 상관이 가장 높았다. 반면 임상집단은 두 총 점 수 간에 모두 유의한 상관을 보였지만, 통제집단에 비해 상관 이 높지 않았다. 각 임상집단별로 $\mathrm{K}-\mathrm{CBCL}$ 총 문제 행동과 기 능평가척도 전체점수와의 상관을 살펴보면, 정서행동문제를 가진 아동 0.203 , 발달장애아동 0.363 , 정서행동문제를 가진 청소년 0.284 의 유의한 상관을 보였다. 통제집단에서는 증상 에 대한 보고와 증상으로 인한 기능의 손상 정도 간에 매우 높은 상관을 보인 반면, 임상집단에서는 증상에 대한 보고와 증상으로 인한 기능손상 정도 간에 유의한 상관은 있으나 상 관수준이 통제집단에 비해 현저히 낮았다. 임상집단 중에서 도 특히 정서행동문제를 가진 아동청소년 집단에서는 불일치 수준이 훨씬 더 크다는 점을 고려할 때, 임상군에는 증상에 관 한 척도뿐만 아니라 기능평가척도를 함께 실시하는 것이 매 우 필요할 것으로 보인다.

\section{확인적 요인분석}

구인타당도를 확인하기 위해 행동 영역에서 가정과 학교, 학 업 및 또래관계, 정서, 특수 영역 각각에 대해 연구자가 지정한 요인수로 고정하여 요인추출방법과 회전 방법으로 각각 주축 요인분석과 direct oblimination을 이용하여 확인적 요인분석 을 하였다(Table 3). 가정에서의 행동영역 요인은 주의력 및 과 잉행동, 반항, 품행 3 개로 고정하였고, 3 개 요인의 초기 고유값 은 전체변량 $41.56 \%$ 를 설명하여 예비연구 결과 $48.10 \%$ 에 비 해 전반적인 설명량이 약간 감소하였다. 그러나 요인별로 문 항구성 및 요인이 적절히 일치하였으며, 특히 예비연구 결과에 비해 본 척도에서는 품행요인의 설명량이 증가하였고 문항 구 성이 일치하고 있어 품행 요인의 구인타당도를 확인할 수 있 다. 학교행동 영역의 요인은 주의력 및 과잉행동, 반항, 품행 3 개로 고정하였고, 3 개 요인의 초기 고유값은 전체변량 $44.26 \%$ 를 설명하여 예비연구 결과 $48.15 \%$ 에 비해 설명량이 약간 감 소하였다. 요인별로는 '요인 1'이 30.40\%, '요인 3'이 4.05\%로 이 


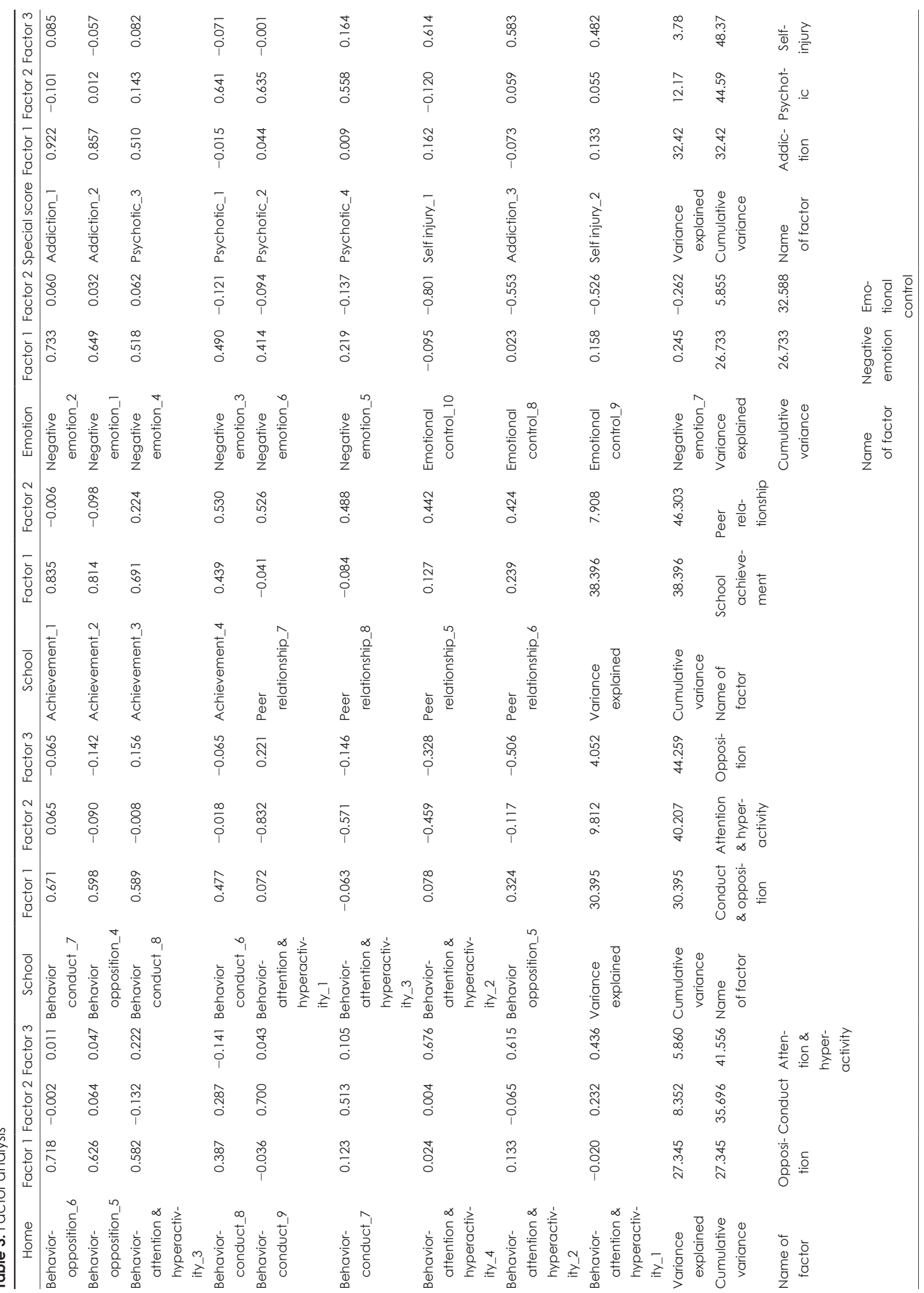


전에 비해 설명변량이 다소 감소한 반면, '요인 2'는 9.81\%로 예 비연구 결과에 비해 설명변량이 상승하였다. 요인 1 의 문항구 성을 살펴보면 품행 문항 3 개와 반항 문항 1 개를 포함하고 있 으며, 요인 2는 주의력 및 과잉행동 문항 3 개로 구성되어 있 다. 그리고 요인 3 은 반항 문항 1 문항로 구성되어 반항 요인과 품행 요인을 명확히 2 개의 요인으로 구분하는 데 어려움이 따 르는 것으로 보인다. 학업 및 또래관계영역의 요인은 학업, 사 회성 2 개로 고정하였고, 2 개 요인의 초기 고유값은 전체변량 $46.30 \%$ 를 설명하여 예비연구 결과 $47.92 \%$ 와 설명량이 거의 유사하였으며, 문항구성 및 요인이 적절히 일치하는 것으로 보 인다. 정서 영역의 요인은 부적 정서, 정서조절 2개로 고정하였 고, 2 개 요인의 초기 고유값은 전체변량 $32.59 \%$ 를 설명하여 예비연구 결과 $35.02 \%$ 와 거의 유사하였다. 예비연구에서는 부적 정서와 정서조절 요인을 2 개의 요인으로 분리하지 못하 였던 반면, 본 연구에서는 문항구성 및 요인이 적절히 일치한 다. 특수 영역의 요인은 중독, 정신병적 영역, 자해 및 타해의 3 개 로 고정하였고, 3 개 요인의 초기 고유값은 전체변량 $48.37 \%$ 를 설명하여 적절한 수준이었다. 인터넷문항이 중독영역에 속하 지 않고, 오히려 자해 및 타해 영역에 포함되어 있는 점을 제외 하고는 특수 영역의 문항구성 및 요인이 적절히 일치한다. 인터 넷 행위중독은 물질중독과 달리 일반적 중독 특성보다는 오 히려 자해 및 타해 영역과 더 유사한 특성을 내포하는 것으로 추측된다.

영역별 확인적 요인분석을 실시한 결과, 본 연구에서 각 영역 별 설명량은 예비연구에 비해 약간 저하되었지만 전반적으로 요인 간의 설명량이 좀 더 고르게 분포되었다. 특히 정서 영역 에서는 부적 정서와 정서조절로 문항구성이 예비연구와 달리 적절하게 구분되었으며, 가정행동 영역에서는 품행요인의 설 명량이 좀 더 증가하였고, 추가로 특수 영역에 대한 요인분석 결과, 문항구성과 요인이 전반적으로 일치하였다.

\section{임상집단과 통제집단의 기능평가 차이(변별타당도)}

각 임상집단(정서행동문제를 가진 아동, 발달장애아동, 정서 행동문제를 가진 청소년)과 통제집단이 가정행동, 학교행동, 학업 및 또래관계, 정서와 특수 영역을 포함한 모든 영역에서 차이가 있는지 알아보기 위해서, 먼저 집단별 일원 ANOVA를 실시했다. 그 결과, 기능평가의 모든 영역에 걸쳐서 집단 간에 유의한 차이가 있는 것으로 나타났다. 이에 따라 영역별로 어 떤 집단 간에 유의한 차이가 있는지 알아보기 위해서 Scheffe 사후검증을 실시하였다.

Table 4와 같이 가정행동의 주의 집중영역에서 모든 임상집 단(정서행동, 발달, 청소년)은 통제집단보다 유의하게 주의집 중의 문제가 있는 것으로 나타났다. 그러나 임상집단군 간에
는 유의한 차이가 없었다. 가정행동의 반항행동 영역에서 정 서행동문제를 가진 초등학생과 청소년 집단은 통제집단에 비 해 유의하게 반항행동이 높았으나, 발달장애 아동집단은 통 제집단과 유의한 차이가 없었다. 가정행동의 품행영역에서도 정서행동문제를 가진 초등학생과 청소년 집단은 통제집단에 비해 유의하게 품행행동이 높았으나, 발달장애 아동집단은 통 제집단과 유의한 차이가 없었다.

학교 주의집중 영역에서 모든 임상집단(정서행동, 발달, 청소 년)은 통제집단보다 유의하게 주의집중의 문제가 있는 것으로 나타났으나, 임상집단군 간에는 유의한 차이가 없었다. 좀 더 구체적으로 살펴보면, 학교행동의 반항행동 영역이나 품행 영 역에서는 정서행동문제를 가진 초등학생집단이 통제집단에 비해 유의하게 반항행동이 높았으나, 발달장애 아동과 정서행 동문제를 가진 청소년집단은 통제집단과 유의한 차이가 없었 다. 학업 영역에서는 모든 임상집단(정서행동, 발달, 청소년)은 통제집단보다 유의하게 학업 문제가 있는 것으로 나타났으며, 특히 발달문제아동은 학습의 어려움이 가장 큰 것으로 나타 났다. 또래관계 영역에서 모든 임상집단(정서행동, 발달, 청소 년)은 통제집단보다 유의하게 또래 문제가 많은 것으로 나타 났다. 그러나 임상집단 간에 유의한 차이가 없었다.

부적 정서 영역에서 정서행동문제를 가진 초등학생과 청소 년은 통제집단보다 유의하게 부적 정서가 높았으며, 특히 청소 년 집단의 부적 정서가 가장 높은 수준이었다. 그러나 발달장 애 아동집단은 통제집단과 부적 정서 영역에서 유의한 차이 가 없었다. 정서조절 영역에서 정서행동문제를 가진 초등학생 과 청소년집단은 통제집단에 비해 유의하게 정서조절의 어려 움을 나타냈다. 그러나 발달장애 아동집단은 통제집단과 정서 조절 면에서 유의한 차이가 없었다.

특수 영역에서 자해나 자살위험의 경우, 정서행동문제를 가 진 초등학생이나 청소년 집단은 통제집단에 비해서 자해나 자 살위험이 유의하게 높았다. 반면에 발달장애 아동집단은 통제 집단과 유의한 차이가 없었다. 중독 영역에서는 정서행동문제 를 가진 초등학생이나 청소년 집단은 통제집단에 비해서 중 독위험이 유의하게 높았으며, 특히 정서행동문제를 가진 청소 년집단이 초등학생 집단보다 더 중독의 문제를 많이 갖고 있 는 것으로 나타났다. 반면에 발달장애 아동집단은 통제집단 과 유의한 차이가 없었다. 정신병적 영역에서 정서행동문제 초 등학생집단은 통제집단에 비해서 특이한 사고를 나타내는 것 으로 보고되었다. 반면에 발달장애집단이나 정서행동문제를 가진 청소년집단은 통제집단과 유의한 차이를 보이지 않았다. 요약하면, 모든 임상집단(정서행동문제를 가진 아동, 발달장 애아동, 정서행동문제를 가진 청소년)은 통제집단과 비교할 때, 가정행동, 학교행동, 학업 및 또래관계, 정서와 특수 영역을 
Table 4. Average, standard deviation and ANOVA of Child-Adolescent Functional Assessment Scale

\begin{tabular}{|c|c|c|c|c|c|c|c|c|c|c|c|c|}
\hline \multirow[b]{2}{*}{ Area } & \multirow[b]{2}{*}{ Subscale } & \multicolumn{4}{|c|}{ Average (SD) } & & \multirow[b]{2}{*}{ SS } & \multirow[b]{2}{*}{$d f$} & \multirow[b]{2}{*}{ MS } & \multirow{2}{*}{$\begin{array}{c}\text { Welch's } \\
\text { F }\end{array}$} & \multirow[b]{2}{*}{$p$} & \multirow[b]{2}{*}{ Post-test } \\
\hline & & Control & $\begin{array}{l}\text { Clinical } \\
\text { group } 1\end{array}$ & $\begin{array}{l}\text { Clinical } \\
\text { group } 2\end{array}$ & $\begin{array}{l}\text { Clinical } \\
\text { group } 3\end{array}$ & & & & & & & \\
\hline \multirow[t]{12}{*}{ Home } & Attention \& & 0.61 & 2.60 & 2.55 & 2.13 & Within & 542.879 & 3 & 180.960 & 163.515 & 0.000 & $c<1,2,3$ \\
\hline & hyperactivity & $(0.93)$ & $(1.33)$ & $(1.44)$ & $(1.47)$ & Between & 1247.962 & 769 & 1.623 & & & \\
\hline & & & & & & Total & 1790.841 & 772 & & & & \\
\hline & Opposition & 0.09 & 0.9 & 0.26 & 0.96 & Within & 104.035 & 3 & 34.678 & 104.695 & 0.000 & C, $2<1,3$ \\
\hline & & $(0.36)$ & $(0.82)$ & $(0.58)$ & $(0.80)$ & Between & 379.082 & 769 & 0.493 & & & \\
\hline & & & & & & Total & 483.118 & 772 & & & & \\
\hline & Conduct & 0.04 & 0.48 & 0.12 & 0.49 & Within & 31.436 & 3 & 10.479 & 35.967 & 0.000 & $C, 2<1,3$ \\
\hline & & $(0.22)$ & $(0.85)$ & $(0.44)$ & $(0.97)$ & Between & 378.999 & 769 & 0.493 & & & \\
\hline & & & & & & Total & 410.435 & 772 & & & & \\
\hline & Home & 0.74 & 3.98 & 2.93 & 3.58 & Within & 1374.751 & 3 & 458.250 & 199.780 & 0.000 & \\
\hline & behavior & $(1.16)$ & $(2.20)$ & $(1.98)$ & $(2.32)$ & Between & 3001.782 & 769 & 3.903 & & & $c<2<1,3$ \\
\hline & & & & & & Total & 4376.533 & 772 & & & & \\
\hline \multirow[t]{18}{*}{ School } & Achievement & 0.73 & 3.04 & 5.77 & 2.84 & Within & 1800.539 & 3 & 600.180 & 330.248 & 0.000 & $c<1,3<2$ \\
\hline & & $(0.91)$ & (2.1) & (1.73) & $(2.01)$ & Between & 2552.002 & 769 & 3.319 & & & \\
\hline & & & & & & Total & 4352.541 & 772 & & & & \\
\hline & Peer & 0.28 & 1.97 & 2.17 & 1.78 & Within & 416.456 & 3 & 138.819 & 174.625 & 0.000 & $c<1,2,3$ \\
\hline & relationship & $(0.52)$ & $(1.63)$ & $(1.36)$ & $(1.64)$ & Between & 1507.901 & 769 & 1.961 & & & \\
\hline & & & & & & Total & 1924.357 & 772 & & & & \\
\hline & Attention \& & 0.11 & 1.18 & 1.29 & 0.96 & Within & 165.598 & 3 & 55.199 & 121.016 & 0.000 & $c<1,2,3$ \\
\hline & hyperactivity & $(0.48)$ & $(1.03)$ & $(1.15)$ & $(1.13)$ & Between & 703.199 & 769 & 0.914 & & & \\
\hline & & & & & & Total & 868.797 & 772 & & & & \\
\hline & Opposition & 0.11 & 0.51 & 0.20 & 0.38 & Within & 24.232 & 3 & 8.077 & 30.966 & 0.000 & $C, 2,3<1$ \\
\hline & & $(0.33)$ & $(0.72)$ & $(0.54)$ & $(0.54)$ & Between & 287.788 & 769 & 0.374 & & & \\
\hline & & & & & & Total & 312.021 & 772 & & & & \\
\hline & Conduct & 0.01 & 0.32 & 0.10 & 0.13 & Within & 14.129 & 3 & 4.710 & 27.453 & 0.000 & $c, 2,3<1$ \\
\hline & & $(0.73)$ & $(0.74)$ & $(0.38)$ & $(0.41)$ & Between & 261.190 & 769 & 0.340 & & & \\
\hline & & & & & & Total & 275.320 & 772 & & & & \\
\hline & School & 0.23 & 2.00 & 1.59 & 1.47 & Within & 412.435 & 3 & 137.478 & 114.873 & 0.000 & $c<1,2,3$ \\
\hline & behavior & $(0.64)$ & $(1.91)$ & $(1.60)$ & (1.58) & Between & 2030.644 & 769 & 2.641 & & & \\
\hline & & & & & & Total & 2443.079 & 772 & & & & \\
\hline \multirow[t]{9}{*}{ Emotion } & Negative & 0.28 & 1.54 & 0.34 & 2.56 & Within & 366.085 & 3 & 122.028 & 78.121 & 0.000 & C, $2<1<3$ \\
\hline & emotion & $(0.73)$ & $(1.63)$ & $(0.67)$ & $(2.05)$ & Between & 1468.469 & 768 & 1.912 & & & \\
\hline & & & & & & Total & 1834.554 & 771 & & & & \\
\hline & Emotion & 0.17 & 1.11 & 0.32 & 1.16 & Within & 146.847 & 3 & 48.949 & 81.054 & 0.000 & C, $2<1,3$ \\
\hline & control & $(0.51)$ & $(1.06)$ & $(0.70)$ & $(1.11)$ & Between & 637.571 & 768 & 0.830 & & & \\
\hline & & & & & & Total & 784.418 & 771 & & & & \\
\hline & Total & 0.45 & 2.65 & 0.66 & 3.71 & Within & 951.609 & 3 & 317.203 & 109.808 & 0.000 & C. $2<1<3$ \\
\hline & & (1.09) & $(2.26)$ & $(1.18)$ & $(2.53)$ & Between & 2844.468 & 768 & 3.704 & & & \\
\hline & & & & & & Total & 3796.076 & 771 & & & & \\
\hline \multirow{9}{*}{$\begin{array}{c}\text { Special } \\
\text { area }\end{array}$} & Self injury \& & 0.02 & 0.33 & 0.05 & 0.40 & Within & 17.858 & 3 & 5.953 & 25.543 & 0.000 & C, $2<1,3$ \\
\hline & suicide & $(0.15)$ & $(0.77)$ & $(0.21)$ & $(0.72)$ & Between & 283.265 & 768 & 0.369 & & & \\
\hline & & & & & & Total & 301.123 & 771 & & & & \\
\hline & Addiction & 0.21 & 0.71 & 0.16 & 1.20 & Within & 68.410 & 3 & 22.803 & 42.219 & 0.000 & C, $2<1<3$ \\
\hline & & $(0.42)$ & (1.09) & $(0.42)$ & $(0.89)$ & Between & 595.346 & 768 & 0.775 & & & \\
\hline & & & & & & Total & 663.755 & 771 & & & & \\
\hline & Psychotic & 0.07 & 0.58 & 0.26 & 0.27 & Within & 37.324 & 3 & 12.441 & 35.031 & 0.000 & $C, 2,3<1$ \\
\hline & & $(0.30)$ & $(0.94)$ & $(0.57)$ & $(0.62)$ & Between & 454.966 & 768 & 0.592 & & & \\
\hline & & & & & & Total & 492.290 & 771 & & & & \\
\hline
\end{tabular}


Table 4. Average, standard deviation and ANOVA of Child-Adolescent Functional Assessment Scale (continued)

\begin{tabular}{|c|c|c|c|c|c|c|c|c|c|c|c|c|}
\hline \multirow[b]{2}{*}{ Area } & \multirow[b]{2}{*}{ Subscale } & \multicolumn{4}{|c|}{ Average (SD) } & & \multirow[b]{2}{*}{ SS } & \multirow[b]{2}{*}{ df } & \multirow[b]{2}{*}{ MS } & \multirow{2}{*}{$\begin{array}{c}\text { Welch's } \\
\text { F }\end{array}$} & \multirow[b]{2}{*}{$\mathrm{p}$} & \multirow[b]{2}{*}{ Post-test } \\
\hline & & Control & $\begin{array}{l}\text { Clinical } \\
\text { group } 1\end{array}$ & $\begin{array}{l}\text { Clinical } \\
\text { group } 2\end{array}$ & $\begin{array}{l}\text { Clinical } \\
\text { group } 3\end{array}$ & & & & & & & \\
\hline \multirow[t]{3}{*}{ Total } & & 2.78 & 14.66 & 13.93 & 15.67 & Within & 19465.024 & 3 & 6488.341 & 257.142 & 0.000 & $c<1,2,3$ \\
\hline & & $(3.12)$ & $(9.62)$ & $(6.50)$ & $(6.50)$ & Between & 44497.015 & 730 & 60.955 & & & \\
\hline & & & & & & Total & 63962.040 & 733 & & & & \\
\hline
\end{tabular}

Control: control group, Clinical group 1: elementary students with emotional \& behavioral disturbances, Clinical group 2: elementary students with developmental disorders, Clinical group 3: middle school students with emotional \& behavioral disturbances. ANOVA: analysis of variance, df: degree of freedom, MS: mean squares, SD: standard deviation, SS: sum of squares

Table 5. Sectional aggregate ranges

\begin{tabular}{|c|c|c|c|c|c|c|c|c|c|c|}
\hline & $\begin{array}{c}\text { Home } \\
\text { behavior }\end{array}$ & $\begin{array}{l}\text { School } \\
\text { behavior }\end{array}$ & $\begin{array}{c}\text { School } \\
\text { achievement }\end{array}$ & $\begin{array}{c}\text { Peer } \\
\text { relationship }\end{array}$ & $\begin{array}{l}\text { Negative } \\
\text { emotion }\end{array}$ & $\begin{array}{l}\text { Emotion } \\
\text { control }\end{array}$ & $\begin{array}{l}\text { Self injury } \\
\text { \& suicide }\end{array}$ & Addiction & Psychotic & Total \\
\hline Normal & $0-37.54$ & $0-41.72$ & $0-41.26$ & $0-40.11$ & $0-42.87$ & $0-42.40$ & $0-46.41$ & $0-44.18$ & $0-45.07$ & $0-38.89$ \\
\hline \multirow[t]{2}{*}{ Latent } & 37.54 & 41.72 & 41.26 & 40.11 & 42.87 & 42.40 & 46.41 & 44.18 & 45.07 & 38.89 \\
\hline & -45.86 & 41.72 & -46.44 & -46.45 & 42.87 & 42.40 & 46.41 & 44.18 & 45.07 & -47.86 \\
\hline \multirow[t]{2}{*}{ Risk } & 45.86 & 41.72 & 46.44 & 46.45 & 42.87 & 42.40 & 46.41 & 44.18 & 45.07 & 47.86 \\
\hline & -58.34 & -58.37 & -46.44 & -59.14 & -55.90 & -62.48 & 46.41 & -54.90 & -57.55 & -57.95 \\
\hline \multirow[t]{2}{*}{ High risk } & 58.34 & 58.37 & 54.75 & 59.14 & 55.90 & 62.48 & 46.41 & 54.90 & 57.55 & 57.95 \\
\hline & -78.44 & -97.26 & -71.44 & -83.84 & -88.00 & -71.250 & -94.680 & -97.950 & -94.720 & -92.93 \\
\hline
\end{tabular}

포함한 전 영역에서 유의한 차이가 있었다. 좀 더 구체적으로 임 상집단 간에 차이를 비교해본 결과, 정서행동문제를 가진 초 등학생이나 청소년집단에 비해서 발달장애집단은 가정행동의 반항이나 품행, 부적인 정서나 정서조절, 특수 영역(자해 및 타 해, 중독, 정신병적 영역)에서 통제집단과 유의한 차이가 없었 다. 이는 본 아동청소년 기능평가척도가 정서행동문제를 가진 아동청소년 집단의 경우에는 변별력이 높은 반면, 발달장애를 가진 아동의 문제를 민감하게 변별하는 데는 어려움을 나타 낸다. 아울러 정서행동문제를 가진 청소년 집단은 초등학생 집단과 거의 유사한 양상을 보였으나, 부적 정서나 중독 면에 서 초등학생 집단보다 어려움이 더 많은 것으로 보고되었다.

\section{아동청소년 기능평가척도의 영역별 척도점수 및 활용 가이드라인}

\section{영역별 척도점수}

본 연구에서는 임상군과 통제군의 기능상의 문제를 변별하 기 위해 T-score를 이용해 규준을 만들었다. 임상군과 통제 군 각 집단의 $25,50,75 \%$ 구간에 해당하는 사분위 점수로 규 준을 작성하였다. 통제군의 $75 \%$ 에 해당하는 집단을 정상군 으로 보았으며, 통제군 $75 \%$ 에서 임상군 $25 \%$ 에 해당하는 집 단을 잠재군, 임상군의 25 75\% 상이에 해당하는 집단을 위 험군, 임상군의 $75 \%$ 이상에 해당하는 집단을 고위험군으로 분류하였다(Table 5).

예비연구에서의 척도 규준은 원점수로 작성되어 있어 영역 마다 점수 범위가 다르기 때문에 한눈에 영역 간 비교가 어려
웠다. 그러나 본 연구에서는 척도 규준을 $\mathrm{T}-\mathrm{score}$ 로 변환하여 영역 간의 대략적인 비교가 가능하도록 하였다(Fig. 1). 또한 예비연구에서의 규준은 크게 가정행동, 학교행동, 학업또래관 계, 총점으로 나누어져 있었으나 본 척도에서는 영역을 보다 세분화하여 규준을 작성함으로써, 좀 더 구체적인 치료 계획 을 세우는 데 도움이 되도록 하였다. 그러나 영역을 세분화하 여 규준을 작성하다 보니 원점수의 범위가 작아져서 $\mathrm{T}-\mathrm{score}$ 로 변환하였을 때 점수 변화가 섬세하지 못하다는 단점이 있 다. 따라서 예비연구에서는 정상, 잠재, 경계, 위험, 고위험 5 개 구간으로 나누었던 것과 달리 본 척도에서는 정상, 잠재, 위 험, 고위험 4개 구간으로 나누어 규준을 만들었다. 특히 학교 행동 영역과 또래관계 영역, 정서 영역의 경우에는 점수 분포 가 극단으로 나누어지는 경향이 있어 3 구간, 즉 정상, 위험, 고 위험으로 나누어 규준을 만들었다. 특수 영역의 경우 자해 및 자살, 중독, 정신병적 각 영역에서 한 문항이라도 표시하여 1 점 이상이면 고위험군으로 분류한다. 그러나 중독 영역에서 인터넷 중독문항은 기능상 곤란을 반영하는 2점 이상부터 고 위험군으로 분류한다(Fig. 2).

\section{아동청소년 기능평가척도의 집단별 적용}

본 연구에서 살펴본 바와 같이 아동청소년 기능평가척도는 임상집단 중에서도 정서행동문제를 가진 아동이나 청소년들 의 기능을 평가하는 데 민감한 척도로 볼 수 있다. 임상집단 간의 변별타당도를 살펴보면, 발달장애를 가진 집단은 주의 력, 학습영역, 또래관계에서 통제집단과 유의한 차이가 있었으 
며, 특히 학습과 또래관계 영역에서는 다른 두 임상집단에 비 해서 발달장애를 가진 아동이 가장 저조한 점수를 보였다. 그 러나 반항/품행/정서(부적 정서, 조절)/특수 영역에서는 발달장 애를 가진 임상집단과 통제집단 간에 유의한 차이가 없었다. 발달장애를 가진 아동들은 기능 수준이 낮고 보호자 없이는 기본적 이동이나 생활이 어려운 아동이 많다. 그러므로 정서 행동문제를 가진 아동과 달리 발달장애를 가진 아동에게는 기본적인 의사소통 능력 및 상호작용 기술, 개인 생활 기술(식 사, 신변처리, 개인 위생 등) 등이 좀 더 측정되어야 할 중요한 영역인 것으로 보인다. 정서행동문제를 가진 청소년(중학생) 집
단은 정서행동문제를 가진 초등학생에 비해 부적 정서나 중독 면에서 특히 더 많은 어려움을 보였다. 그러나 본 연구에 포함 된 중학생 피험자수가 상대적으로 적었을 뿐만 아니라, 중학생 규준이 없기 때문에 이 연령층에 대한 후속 연구가 필요하다.

\section{아동청소년 기능평가척도의 해석 가이드라인}

오늘날 정신건강 서비스 분야에서는 평가나 치료적인 서비 스를 제공할 때 비용 대비 효과가 얼마나 있는지 점차 증명을 요구하고 있다. ${ }^{17)}$ 평가도구의 경우, 비용 대비하여 평가도구가 내담자의 문제를 얼마나 신속하게 파악할 수 있으며, 평가 결

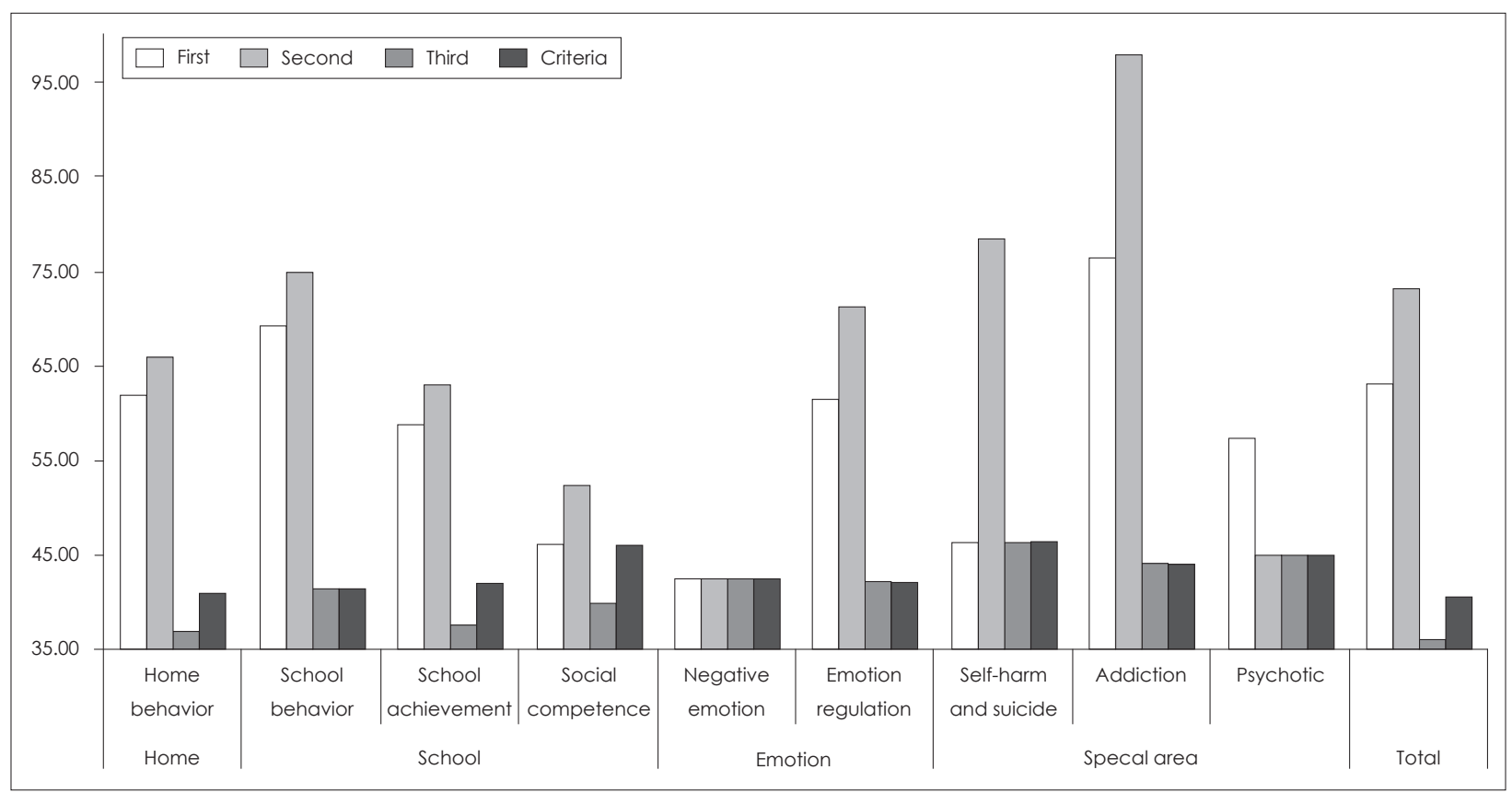

Fig. 1. Child-Adolescent Functional Assessment Scale_graph example.

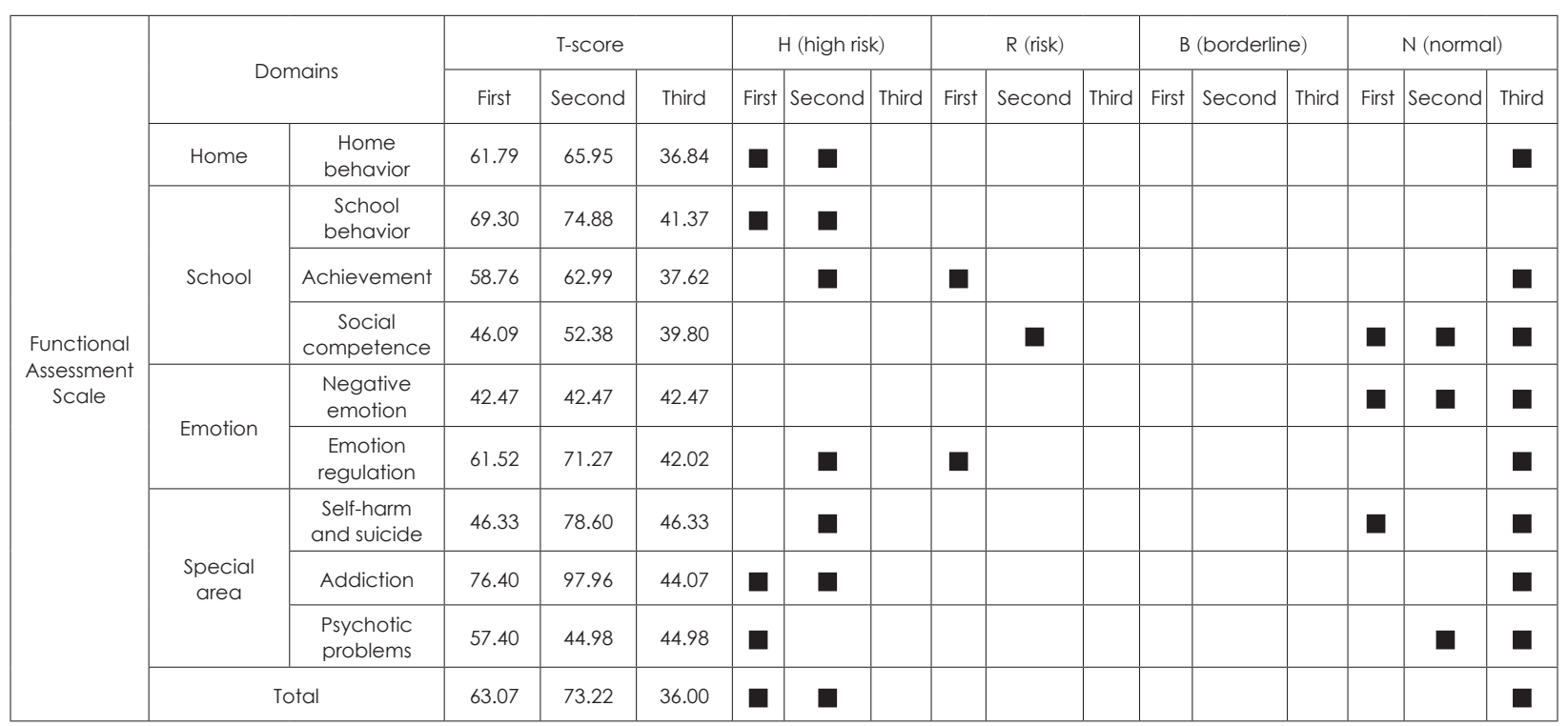

Fig. 2. Child-Adolescent Functional Assessment Scale_table example. 
과를 바탕으로 빠르고 효과적인 치료계획을 세우고, 잘못 배 치하거나, 혹은 불필요한 장기치료를 피하여 비용 절감을 할 수 있는지, 실제로 개입한 효과를 보여줄 수 있는지 여부가 매 우 중요하다. 이러한 측면에서 볼 때, 아동청소년 기능평가척 도는 개인의 기능수준을 다른 아동청소년 집단과 비교할 수 있을 뿐만 아니라, 아동의 개인 내 변화를 영역별로 살펴볼 수 있다. 또한 표준점수를 통해 개인 내 여러 영역들(가정, 학교, 정 서, 특수 영역) 간에 심한 정도를 대략적으로 비교 가능하다.

본 연구 결과를 바탕으로 사례관리 및 치료계획을 세우는 데 도움이 될 수 있도록 전반적인 해석 가이드라인은 다음과 같다. 먼저, 합산점수를 통해 전체적인 수준을 파악한다. 예를 들어, 정상과 잠재군은 비임상군으로 개입이 요구되지 않는 다. 특히 정상 수준에 해당되면 이를 강점 자원, 혹은 보호요 인으로 간주할 수 있다. 반면에 위험군과 고위험군은 임상군으 로 개입이 요구된다. 둘째로 긴급하게 먼저 개입해야할 영역을 파악한다(urgency). 특히 자해나 타해, 중독, 정신병적 영역에 해당되는 경우, 개입의 우선순위를 둔다. 셋째, 아동의 문제 심 각성이 얼마나 다양한 영역에 편재되어 있는지(pervasive) 확 인한다. 즉 위험군이나 고위험군에 속하는 영역은 얼마나 되 는지, 문제가 가정, 학교, 혹은 모든 세팅에서 다 일어나는지 여 부를 점검한다. 넷째로 어느 영역에서의 문제가 가장 심각한 수준인지(severity) 확인한다. 마지막으로 전반적인 아동의 기 능수준을 점검해보고, 정서인식이나 조절은 기능수준과 비교 하여 적절한지 여부를 검토한다.

\section{고 찰}

본 연구는 아동청소년 기능평가척도의 제한점을 보완하고 이를 좀 더 다양하게 활용하기 위하여 척도의 영역별 T점수 기준 및 활용 가이드라인을 제시하였다. 이를 위해 아동청소 년 기능평가척도와 $\mathrm{K}-\mathrm{CBCL}$ 를 여러 임상집단과 중학생 연령 층으로 확장하여 실시하였다. 먼저 아동청소년 기능평가척도 의 타당성을 검증하기 위해서 예비연구 결과와 비교해본 결 과, 신뢰도, 항목-전체 상관계수와 타당도는 전반적으로 예비 연구의 결과와 거의 유사하였다. 하지만 요인별로는 예비연구 에 비해 오히려 좀 더 고르게 신뢰도나 타당도가 안정적으로 보고되었다. 특히 본 연구에서는 예비연구에 비해서 품행요인 의 설명량이 증가하였고 정서 영역에서는 부적 정서와 정서조 절 2개 요인을 분리할 수 있었다. 다만, 예비연구와 달리 표집 대상의 임상군을 보다 다양화함에 따라, 본연구의 전반적인 신뢰도나 타당도 수치가 예비연구 결과에 비해 미세하게 하락 된 경향이 있었고, 정서행동문제를 가진 중학생 연령층의 임 상군의 수가 상대적으로 적어서 반항요인과 품행요인을 명확
히 구분하는 데는 어려움이 있는 것으로 보인다.

본 연구의 가장 큰 의의는 규준을 예비연구와 같이 원점수 로 제시하지 않고 T점수를 산출하여 제시한 점이다. 이를 통 해 어느 영역에서 문제가 더 심각한지 개인 내 비교가 가능하 도록 하였다. 따라서 아동청소년 기능평가척도는 전반적인 기 능평가척도인 CGAS와 비교해볼 때, 다양한 영역에 대한 평 가가 가능할 뿐만 아니라, 개인 영역 내 심각도 수준을 비교 할 수 있으며, 개인 간에도 비교 가능한 규준을 제공한다. 뿐 만 아니라, 이를 기반으로 사례관리 및 치료계획을 세우는 데 도움이 될 수 있도록 전반적인 해석 가이드라인을 제시한다.

반면에 본 척도의 제한점은 다음과 같다. 첫째, 이 척도는 현 재 초등학생을 대상으로 하는 규준만 제공되기 때문에 정서 행동문제를 가진 초등학령기 아동들에 대한 평가에 가장 민 감하게 적용될 수 있다. 그러므로 차후에는 연령 확대를 통해 청소년(중학생) 연령별 규준이 마련되어야 할 것이다. 둘째, 본 척도가 CGAS의 단점을 보완하는 데 초점을 맞추었기 때문에 CGAS처럼 증상의 심각도와 심리장애로 인한 기능손상 간에 경계가 다소 불분명한 문항들이 있다. 이는 단지 척도의 제한 점일 뿐만 아니라, DSM-5와 같은 정신장애 진단기준에 증상 과 함께 기능손상이나 주관적 고통이란 기준도 포함되므로 증상과 기능손상을 명확하게 구분 짓기가 어려운 실정이다.

\section{결 론}

아동청소년의 치료서비스 효과를 이해하고 검증하기 위해 서는 아동의 증상뿐만 아니라, 가정, 학교와 지역사회에서 아 동청소년의 기능(functioning)을 측정하는 것이 절실히 요구된 다. 본 논문의 아동청소년 기능평가척도는 아동청소년의 전반 적인 증상을 포괄적으로 평가하는 한국판-아동청소년 행동 평가척도 $(\mathrm{K}-\mathrm{CBCL})$ 나 $\mathrm{K}-\mathrm{CBCL}$ 을 위한 아동 정서·행동발달 선별검사와 달리 증상보다 기능 위주로 평가하는 데 초점을 맞추어 개발되었다. 또한 아동청소년 기능평가척도는 실무자 용인데 반해, $\mathrm{K}-\mathrm{CBCL}$ 은 부모 보고식 척도이다. 본 연구결과 에 의하면, 정서행동문제를 가진 임상군은 아동청소년 기능평 가와 $\mathrm{K}-\mathrm{CBCL}$ 의 상관관계가 다른 집단에 비해서 다소 낮은 편이다. 즉 부모가 보고한 증상에 대한 평가와 실무자에 의한 기능 평가 간 불일치 정도가 다른 집단에 비해 약간 높은 점을 감안할 때, 부모 보고에 의한 척도뿐만 아니라, 실무자에 의한 평가 척도가 필요할 것으로 보인다. 국내 임상이나 연구 장면 에서 가장 널리 활용되는 아동총괄기능평가척도(CGAS)는 단 일 점수로 제시되기 때문에 전반적인 평가만 가능한 반면, 아 동청소년 기능평가척도는 현장에서 단시간 내 영역별로 좀 더 세분화된 정보를 얻을 수 있도록 개발되었다. 이 척도는 호주 
의 HoNOSCA에 비해 채점자의 주관적인 견해가 덜 개입되도 록 행동상 기능을 평가하는 문항을 위주로 제작하였으며, 미 국의 CAFAS와 비교할 때 우리나라 상황에 적합하지 않은 다 수의 문항을 제거하고 우리 실정에 맞도록 제작되었다.

그러나 예비연구를 통해 제작된 아동청소년 기능평가척도 는 규준이 원점수로 제공되어 개인 내 여러 영역 간 비교가 어 려운 제한점을 갖고 있다. 따라서 본 연구는 이러한 단점을 보 완하기 위해 세분화된 영역별 $\mathrm{T}$ 점수 기준을 제시하고, 정신보 건시스템 내에서 더 잘 활용되도록 전반적인 활용 가이드라인 을 제공한다. 아동청소년 기능평가척도는 효과검증을 위한 도 구일 뿐 아니라, 현장에서 사례관리를 하거나 치료목표 수립 시에도 개입 순위를 정하며, 개입 전략을 세울 때 유용하다. 예를 들어, 정서 영역 내에서 부적 정서와 정서조절로 인한 어 려움을 구분함으로써 좀 더 구체적인 정보를 제공한다. 본 척 도가 다양한 장면에서 비용, 시간 대비 좀 더 효과적인 평가와 개입이 가능한 도구로 널리 활용될 수 있기를 기대하며, 이를 위해서는 좀 더 다양한 연령층에 대한 규준과 더불어 경험적 자료에 근거한 사례관리나 치료계획을 위한 구체적 지침들이 뒷받침 되어야 할 것이다.

중심 단어:기능평가척도; 아동과 청소년; 정신건강 서비스; 타당도; 활용.

\section{Acknowledgments}

본 연구는 서울시 지원으로 수행되었습니다.

\section{Conflicts of Interest}

The author has no financial conflicts of interest.

\section{REFERENCES}

1) Hoagwood K, Jensen PS, Petti T, Burns BJ. Outcomes of mental health care for children and adolescents: I. A comprehensive conceptual model. J Am Acad Child Adolesc Psychiatry 1996;35:10551063

2) Jensen PS, Hoagwood K, Petti T. Outcomes of mental health care for children and adolescents: II. Literature review and application of a comprehensive model. J Am Acad Child Adolesc Psychiatry 1996;35:1064-1077.
3) Bird HR, Yager TJ, Staghezza B, Gould MS, Canino G, Rubio-Stipec M. Impairment in the epidemiological measurement of childhood psychopathology in the community. J Am Acad Child Adolesc Psychiatry 1990;29:796-803.

4) Shaffer D, Gould MS, Brasic J, Ambrosini P, Fisher P, Bird H, et al. A children's global assessment scale (CGAS). Arch Gen Psychiatry 1983;40:1228-1231.

5) Barkley RA. Barkley functional impairment scale: children and adolescents (BFIS-CA). New York, NY: Guilford Press;2012.

6) American Psychiatric Association. Diagnostic and Statistical Manual of Mental Disorders: DSM-IV. 4th ed. Washington, DC: American Psychiatric Association;1994.

7) Simeonsson RJ, Leonardi M, Lollar D, Bjorck-Akesson E, Hollenweger J, Martinuzzi A. Applying the International Classification of Functioning, Disability and Health (ICF) to measure childhood disability. Disabil Rehabil 2003;25:602-610.

8) World Health Organization. International Classification of Functioning, Disability and Health: children and youth version: ICF-CY. Geneva: World Health Organization;2007.

9) Canino GJ, Fisher PW, Alegria M, Bird HR. Assessing child impairment in functioning in different contexts: implications for use of services and the classification of psychiatric disorders. Open J Med Psychol 2013;2:29-34.

10) Gold LH. DSM-5 and the assessment of functioning: the World Health Organization Disability Assessment Schedule 2.0 (WHODAS 2.0). J Am Acad Psychiatry Law 2014;42:173-181.

11) Row KR, Suh DS. A preliminary study for developing a Child and Adolescent Functional Assessment Scale in the mental health service. J Korean Acad Child Adolesc Psychiatry 2014;25:142-155.

12) Hodges K. The Child and Adolescent Functional Assessment Scale (CAFAS). In: Maruish ME, editors. The use of psychological testing for treatment planning and outcome assessment. 3rd ed. Mahwah, NJ: Lawrence Erlbaum Associates;2004. p.405-441.

13) Brann P, Coleman G, Luk E. Routine outcome measurement in a child and adolescent mental health service: an evaluation of HoNOSCA. The Health of the Nation Outcome Scales for children and adolescents. Aust N Z J Psychiatry 2001;35:370-376.

14) Achenbach TM, Edelbrock CS. Manual for the Child Behavior Checklist and revised child behavior profile. Burlington, VT: University of Vermont, Department of Psychiatry;1983.

15) Achenbach TM. Manual for the Child Behavior Checklist/4-18 and 1991 profile. Burlington, VT: University of Vermont, Department of Psychiatry; 1991.

16) Oh KJ, Lee H, Hong KE, Ha EH. Korean child behavior checklist. Seoul, Korea: Chung Ang Aptitude;1997.

17) Groth-Marnat G. Handbook of psychological assessment. 5th ed. Hoboken, NJ: John Wiley \& Sons Inc.;2009. 